Published on Reviews in History (https://reviews.history.ac.uk)

\title{
Reformations: The Early Modern World, 1450-1650
}

Review Number: 2109

Publish date: Thursday, 18 May, 2017

Author: Carlos Eire

ISBN: 9780300111927

Date of Publication: 2016

Price: $£ 22.50$

Pages: 920pp.

Publisher: Yale University Press

Publisher url: http://yalebooks.com/book/9780300111927/reformations

Place of Publication: New Haven, CT

Reviewer: Sam Kennerley

Carlos Eire's Reformations aims to provide a readership of 'beginners and nonspecialists' (p. xii) with an introduction to European history between 1450 and 1650. Eire narrows down this immense task by concentrating his narrative on the history of religion. The central event of his book is the Reformation, the splitting of Western Christianity into Protestant and Catholic churches that began in 1517 with Martin Luther's Ninety-Five Theses. But one of Eire's key contentions is that the whole of early modern history in Europe can be seen as a series of reformations that either flowed into or out of that of Luther. This contention is explored in four main sections: 'On the edge', which deals with Europe between 1450 and 1517, 'Protestants', which studies the rise of Protestantism, 'Catholics', which follows how the Catholic church responded to Protestantism, and finally 'Consequences', which retraces the impact of the Reformation on later 16th- and 17th-century Europe.

Works of such ambition and scope tend to be substantial, and Eire's narrative is no different, spanning over 757 richly illustrated but un-footnoted pages (endnotes, bibliography and an index follow the main narrative). Readers leafing the book from cover to cover will learn a great deal, but groups of chapters have an internal consistency that also makes the book appropriate for readers with more specific aims in mind. Eire's first three chapters offer a background to the later 15th and early 16th-century. In his first chapter ('Age of Breakthroughs'), Eire argues that Europe had already gone through a series of reformations in the late 15th century, well before Luther arrived on the scene: the 'discovery' of the Americas, the arrival of the printing press in Europe, urbanisation, changes in warfare, and the growth of bureaucracy and ever-more forceful assertions of royal sovereignty. His second chapter ('Religion in late medieval Christendom') explores the late medieval church and its principle rites, while the third chapter ('Reform and dissent in the Late Middle Ages') looks instead at groups that stood outside of late medieval orthodoxy. From these two chapters, Eire concludes that religion was a ubiquitous presence in late medieval Europe, a ubiquity that inevitably drew the attention of contemporaries to its flaws. Combined with the drastic changes in society, culture, the military and politics outlined in the first chapter, Eire asserts that Europeans born after 1480 were more willing to embrace change than their forebears had ever been before. The result was a powderkeg Europe ready to explode into religious dissent, given the right conditions.

Eire's next three chapters move from social and cultural history to the history of ideas. His fourth chapter 
('Italian humanism') looks at a way of thinking that is often considered to define a period of its own, namely Renaissance humanism. Drawing on a strong trend in recent scholarship (for example Anthony Grafton's What Was History? (1)), Eire defines humanism as a way of doing history, a critical approach to the past (whether that of ancient Rome or Greece, or of early Christianity) that drew on the lessons of antiquity to reshape the present. Leonardo Bruni, Flavio Biondo and Lorenzo Valla are offered here as exemplars of Italian humanism, but Eire also looks at the political thought of Niccolo Machiavelli and Francesco Guicciardini, as well as the philosophy of Marsilio Ficino and Pico della Mirandola. The next chapter ('Humanism beyond Italy') follows how humanism spread from Italy to the rest of Europe, which here means the German lands, Spain, England and France. Eire's narrative sometimes characterises humanism in a given nation through a single event or figure (such as the Reuchlin controversy in the German lands, or Jacques Lefevre d'Etaples in France), but I found his section on Spanish humanism especially helpful in bringing to attention a wide cast of figures from a country often neglected in studies of Renaissance humanism. Nonetheless, the longest part of this chapter is dedicated to the Dutch scholar Desiderius Erasmus (c.1466-1536), characterised by Eire as a Neoplatonist whose strict sense of the superiority of the spiritual realm over that of the body led him to doubt the core rituals of Catholicism, thereby paving the way for the work of later reformers. Eire's portrait stands out against recent scholarship that has found interest in Erasmus as an editor and translator of ancient texts. This is welcome, but it would have been good to have briefly discussed how Erasmus' clear interest in the liturgy (as in the liturgy for the Virgin of Loreto that he composed in 1523) is to be squared with his apparent rejection of Catholic rites. The first section of the book ends with a chapter titled 'Forerunners of the Catholic Reformation', which sets out to provide an introduction to figures who attempted to reform the Catholic Church before 1517. Here it is worth noting that many of those studied in this chapter, such as Gian Matteo Giberti and St John of the Cross, were most active after the Reformation had already begun.

Having provided a background to the developments of 16th-century Europe, Eire then moves into his second section, which is about the Protestant Reformation. Chapters seven to nine sketch a life of Martin Luther, whose Ninety-Five Theses of 1517, as noted above, put a torch to the powder keg of late medieval religion in Europe. Chapter seven ('Luther: from student to monk') follows Luther's life from his birth in 1483, to his entry into an Augustinian monastery in 1505, his spiritual struggles, and finally his fateful protest of 1517. Chapter eight ('Luther: from rebel to heretic') continues the narrative down to 1522, examining Luther's role at the council of Worms, and his flight to the Wartburg castle. The next chapter ('Luther: the reactionary') switches the focus somewhat. Based more on Luther's enemies than the Reformer himself, this chapter traces Luther's response to the radical Protestants Karlstadt and Zwilling, the Peasant's Rebellion, and finally how the Catholic emperor Charles V and his wars shaped the development of early Protestantism. 
The next four chapters branch out to study Protestant movements that were outside of Luther's direct control. The first of these chapters ('The Swiss Reformation') provides an account of the early years of the Reformed church in Switzerland. This chapter is largely dedicated to Ulrich Zwingli and his work in Zurich, but it has pendants on Basel, Bern, and the Marburg Colloquy. One of Eire's main contentions in this chapter is the distinction between the Swiss and Lutherans, where he finds the Swiss to be more iconoclastic and fond of establishing broader divides between the body and the spirit than their Lutheran neighbours. Chapter 11, titled the 'Radical Reformation', then explores the varieties of 'radical' Protestantism that developed after 1517. Slightly adapting the scheme of G. H. Williams, Eire breaks these radicals into three main groups: Anabaptists (the Swiss Brethren, Munsterites, Karlstadt and others), Spiritualists (from John Denck to Caspar Schwenckfeld), and finally the Evangelical Rationalists (Giorgio Biandrata, Michael Servetus, the Socinians, Unitarians). The next chapter of this section ('Calvin and "Calvinism"') examines the life of John Calvin and how his movement spread across Europe into a church to rival that of Luther. This group of studies is rounded off with a chapter on 'England, Wales, Ireland and Scotland, 1521-1603'. Each of these countries in the British Isles is studied separately, with England receiving the lion's share of attention, followed in descending order by Scotland, Ireland, and Wales. The development of Anglicanism into a church distinct from other Protestant traditions provides the implicit reason for why the British Isles receive their own study, whereas other countries in Europe do not.

These four chapters, especially the one on radical Protestantism, are narrated with a pace and colour that makes them a pleasure to read. Nonetheless, the section that follows - dedicated to developments in the Catholic Church after 1517 - is arguably the richest in Eire's book. Historians have long debated what to call the events that took place in the Catholic Church after 1517: should we call it the Catholic Reformation, the Counter Reformation, or perhaps both? Eire's first chapter of this section ('Facing the challenge') makes a univocal claim in this regard. He argues that Catholic history after 1517 was a Counter-Reformation, in which Catholics responded to Protestantism by whole-heartedly embracing, and thereby reaffirming, all of the doctrines that Protestantism had sought to dismiss. Protestants for their part did the same, constructing a faith that was consciously defined in opposition to the Catholic Church. Eire's next chapter ('Healing the body of Christ') explores this idea at greater length. Eire argues that the distinction between Protestant and Catholic reform can be found in two principal binaries: whereas the Catholic Counter-Reformation was clerical and otherworldly in character, the Protestant Reformation was instead lay and materialistic. This dichotomy is explored through concrete examples in the development of the Catholic Church after the Reformation, such as in the editing of new liturgical texts, reaffirmed belief in the cult of the saints and in miracles, and the proliferation of lay confraternities. The next two chapters in this section further explore the process of reform within Catholicism. In the first ('Fashioning a new clergy'), Eire explores the training of Catholic clerics in the wake of the Reformation, a chapter that needed to exist due to his definition of the Counter-Reformation as clerically driven. There is a short section on the training of the secular clergy, but the bulk of the chapter is given over to the regular clergy, both old orders and new. The next chapter ('The Society of Jesus') is dedicated to just one of these new orders, the Jesuits, studying the life of the order's founder, Ignatius Loyola, its schools, preaching, political activity, and development of the principle of casuistry.

Nonetheless, the Jesuits' most famous contribution to early modern history is their role as missionaries in lands newly known to Europeans in these centuries. This topic provides the focus of Eire's next two chapters. Chapter 18, 'Missions to the New World', follows Catholic missions to the Americas, covering the period from the arrival of the first Catholic clerics with Columbus' second voyage in 1493 until the mid-18th century. Chapter 19 ('Missions to the East Indies') provides a similar overview of Catholic missions to Asia and Africa during the same period.

As this might suggest, these two chapters offer a history of how European Christianity spread to Asia, Africa and the Americas during the early modern period. As Eire notes, this topic has tended not to be addressed in textbook accounts early modern Europe (p. xvi). Eire's chapters are therefore to be commended, but it is possible to take issue with the way that the missionary process is presented here. First of all, this is very 
much a history of Catholic missions. Eire argues that the Protestant missions of the 17th and 18th centuries arrived too late to be within his purview. Yet his narrative of Catholic missions to the New and Old Worlds frequently covers the 17th century, and occasionally (as in on China on p.512) moves into the 18th century. Another potential objection is the manner in which the narrative has been framed. Eire often evaluates missions in terms of their 'success' (as calculated by the number of converts), and applies adjectives such as 'heroic' to the missionaries or to their work (p. 497, p. 518). The implication of these chapters is that the Christianisation of other lands by religious orders, especially the Jesuits, was an essentially praiseworthy activity, whose full potential was impeded by the negative influence of secular priests and authorities. Some readers may object to this presentation of events.

Eire's two chapters on the spread of European Christianity outside of the continent close the third section of his book. The next section instead explores the 'Consequences' of the Reformation, that is to say the impact of the Reformation within Europe. Chapters 20 to 22 retrace how Europe's religious geography turned into a patchwork of competing states and ideologies in the course of the 16th and 17th century. The first of these chapters is entitled 'The age of religious wars', but in reality it looks at religious violence in Europe in general. The following chapter ('The age of orthodoxy') examines the internal struggles within the Lutheran, Reformed and Catholic churches that led to the formation of doctrinal orthodoxy in each tradition. Finally, a chapter entitled 'The confessional age' uses both Jean Delumeau's 'Christianisation' thesis (which proposed that the early modern period saw the first deep Christianisation of Europe) and the 'confessionalisation' thesis of Heinz Schilling and Wolfgang Reinhard (which is more interested in the link between religion and state-building) to explore how religious orthodoxy was enforced within Catholic and Protestant Europe.

Moving away from doctrine and high politics, the final four chapters of the book offer an introduction to the belief-systems of post-Reformation Europe. The chapter 'The age of devils' examines deviant supernatural beliefs that existed within early modern Europe, such as superstition, magic and witchcraft. The next chapter, 'The age of reasonable doubt', then identifies seven ways of thinking that led to doubts about the truth of religion as a whole. These categories range from popular atheism to elite freethinking, but much space given over to the argument that science and religion were opponents throughout the early modern period, a proposal that works such as Robin Barnes' Astrology and Reformation (2) complicate somewhat. The final three chapters explore in greater detail some core themes already raised earlier in the book. 'The age of outcomes' argues that the Protestant laicisation of the clergy caused a dramatic change of thinking about political philosophy, poor relief, sex, and family life. The chapter 'The spirit of the age' makes a similar argument to that of the earlier chapter 'Healing the body of Christ', proposing that while Protestants sought to separate the sacred and the profane, Catholics tended to mix it, which Eire argues led to the 'Baroque' style characteristic of much early modern Catholicism. Eire's 'Epilogue' turns the themes of this last chapter into a theory. Drawing on the thought of Thomas Kuhn, Eire argues that the Reformation was a 'paradigm shift', a change in perspective that meant that the world could not be looked at the same way after Luther's protest. The most profound changes of this 'paradigm shift', Eire argues, were caused by Protestant 'desacralisation' of the world, which saw Protestants separate the material and the supernatural, and Catholics bring them closer together. Eire argues that these changes were most manifest in how each religion responded to the relationship between matter and the spirit, the natural and the supernatural, and the living and the dead.

The theory that religion in post-Reformation Europe was defined by a clash between polar opposites is a central theme of Eire's book. Throughout, Eire argues that Protestants constructed their faith in opposition to late medieval Catholicism, and that Catholics responded by reasserting and reemphasising everything that Protestantism had rejected. It is perhaps for this reason that everything beyond the struggle between these titanic forces gets left out. For instance, it may have enriched a study of religion in early modern Europe to hear more about religious groups on the continent who were neither Catholic nor Protestant, such as Jews, Muslims, or indeed Christians from Greece or even further east who were present in Europe in not inconsiderable numbers. I was also struck by how little was said about commerce between the different churches, whether by conversion (by no means an uncommon experience), or less dramatic forms of 
exchange such as in the arts or sciences. But despite these objections, there can be little doubt that Eire's book achieves what it sets out to do. It provides a readable and stimulating overview of European history between 1450 and 1650 (and often well into the 18th century) that is accessible to newcomers to the discipline, while being sufficiently broad and well-researched to be useful to specialists in early modern history who wish to know more about aspects of the period outside of their area of expertise.

\section{Notes}

1. Anthony Grafton, What Was History? The Art of History in Early Modern Europe (Cambridge, 2017). Back to (1)

2. Robin Barnes, Astrology and Reformation (Oxford, 2016).Back to (2)

\section{Other reviews:}

New York Times

https://www.nytimes.com/2016/08/14/books/review/reformations-carlos-m-n-eire.html [2]

Source URL:https://reviews.history.ac.uk/review/2109

\section{Links}

[1] https://reviews.history.ac.uk/item/198083

[2] https://www.nytimes.com/2016/08/14/books/review/reformations-carlos-m-n-eire.html?_r=0 